\title{
超音波振動およびレーザーを用いた固体面上の 液滴の駆動に関する研究*
}

加 藤 健 司 ${ }^{* 1}$, 脇 本 辰 郎*1, 增 田 良 平*2

\author{
A New Method to Actuate a Droplet on a Plate \\ by Use of Laser and Ultrasonic Oscillation
}

\author{
Kenji $\mathrm{KATOH}^{* 3}$, Tatsuro WAKIMOTO and Ryohei MASUDA \\ ${ }^{*}$ Department of Mechanical Engineering, Osaka City University, \\ 3-3-138 Sugimoto, Sumiyoshi-ku, Osaka-shi, Osaka, 558-8585 Japan
}

\begin{abstract}
A new method to actuate a small droplet on a plate was proposed. In order to reduce the resistance to the droplet movement, which is typically represented by the resultant of surface tension acting on the three-phase contact line, i.e., $\sigma\left(\cos \theta_{R}-\cos \theta_{A}\right)\left(\sigma\right.$ : liquid surface tension, $\theta_{R}, \theta_{A}$ : receding and advancing contact angles), a supersonic oscillation was imposed on the plate to suppress the contact angle hysteresis $\left(\theta_{R}-\theta_{A}\right)$. The experimental results using SAMs (Self-Assembled Monolayers) plates showed that the resistance was reduced by $80 \%$ due to the oscillation having the frequency of $28 \mathrm{kHz}$ and the amplitude of few micrometers. Then the Laser beam was directed to one end of the droplet. The contact angle was remarkably decreased due to the local heating of SAMs plate and the droplet moved to the end of the Laser beam, since the tangential component of surface tension at the heated end overcomes that on the other. The droplet can be actuated by about $0.6 \mathrm{~mm} / \mathrm{s}$ by the method combining the oscillation and the local heating by the Laser beam.
\end{abstract}

Key Words: Interfacial Phenomena, Liquid Droplet, Microfluidics, Laser, Actuation, Surface Tension, Contact Angle, Wettability, Supersonic Oscillation

\section{1. 緒言}

化学·光学機器や医薬関連の分野において, マイクロ 流路における伝熱や反応，あるいはマイクロ流体素子 など，微小スケールの液体運動を制御寸る必要性が高 まっている.このような問題では，表面張力やぬれ性 といった界面現象の影響が重要となる，最近では，温 度差, 電場, 光化学反応あるいはマランゴ二効果など を利用して，局所的に表面張力やぬ性を変化させ， 液滴の運動や分離，あるいは微小流路内の液柱の位置 制御や分岐を行う手法について検討が行われている (1)(6).

本研究は，固体面上の液滴を運動制御する新たな手 法の提案を目的としている。 これまで著者らは，外力 が液滴に作用する系として，傾斜平板あるいは回転円 板上の液滴の移動条件について理論的，実験的に検討 を行ってきた鸟（11)．液滴が移動を開始する力学的な条 件を理論的に導き，実際の液滴挙動がよく説明できる

* 原稿受付 2010 年 4 月 7 日.

*1 正員, 大阪市立大学大学院工学研究科(苾558-8585 大阪市 住吉区杉本 3-3-138).

*2 大阪市立大学大学院工学研究科.

E-mail : katoh@mech.eng.osaka-cu.ac.jp
ことを示した．液滴が平板上を運動する際，液滴に作 用する表面張力が抵抗となるが，その大きさは液滴の 両端に現れる接触角の差(接触角履歷)に大きく依存す る. 本研究では, 液滴運動の抵抗をできる限り小さく するよう，壁面に超音波振動を施して接触角履歴を低 減する方法について検討を行う。また，外部からレー ザーを液滴の一端に照射して，固体表面のぬれれ性の変 化を誘起することにより，液滴を駆動する手法を試み る.

ここでは，まず超音波振動の振幅を変化させ，試料 平板と供試夜体の種々の組み合わせについて，接触角 履歷の大きさを測定するとともに，液滴が転落を開始 する傾斜角度の測定を行う．得られた測定結果に基づ き，振動による抵抗低減効果について検討を行う。つ いで，超音波振動を与えた種々の条件の下，レ一ザー 出力を変化させて液滴の駆動実験を行う．液滴が運動 を開始するまでの接触角の変化や，液滴を移動させる ために必要な超音波振動子の振幅とレーザー出力の関 係について実験的に検討を行う。

\section{2. 液滴駆動の方法}


$2 \cdot 1$ 接触角履歴の低減 図 1 のように，水平な 固体面に付着した液滴が外力を受け，図の $x$ 方向に移 動する場合を考える. 液滴が移動する瞬間における固 気液 3 相の接触線(図 1.のC)のぬれ挙動の考察から, 液体の表面張力 $\sigma$ の液滴周囲に作用する合力 $D$ は, 次 式により与えられる(7).

$$
D=\sigma\left(\cos \theta_{R}-\cos \theta_{A}\right) b
$$

ここで, $\theta_{\mathrm{R}}$ および $\theta_{\mathrm{A}}$ は，接触線上に現れる後退および 前進接触角である. また, $b$ は液滴付着面の最大幅で ある. 式(1)は，任意の付着面形状の液滴について成立 する. 重力や遠心力などの外力が式(1)の $D$ よりも大き くなると，液滴は移動を開始する，上式より，接触角 履歷 $\left(\theta_{\mathrm{A}}-\theta_{\mathrm{R}}\right)$ を小さくすることにより，抵抗を低減で きることがわかる。

接触角履歷は, 固体面上に存在するあらさや化学的 な不均質部分などの欠陥の存在により現れるとされて いる. 接触角履歷が現れるメカニズムについて, 表面 上の欠宿部を接触線が通過する際に必要な仕事量との 関連が指摘されている( ${ }^{(12)(13)}$. 図 2 は，巨視的な接触角 $\theta_{\mathrm{R}}$ をもち，固体面上の欠陷を通過する接触線の挙動を

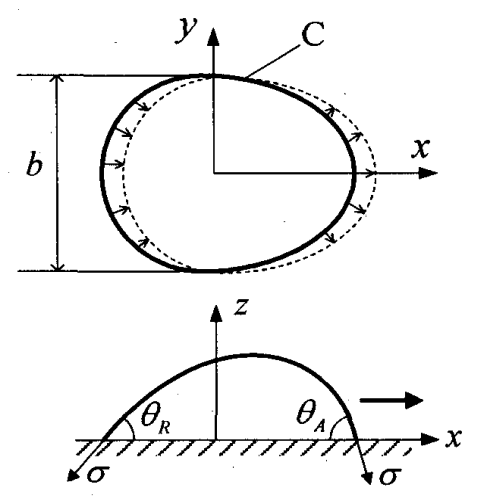

Fig 1 Schematic of liquid droplet movement

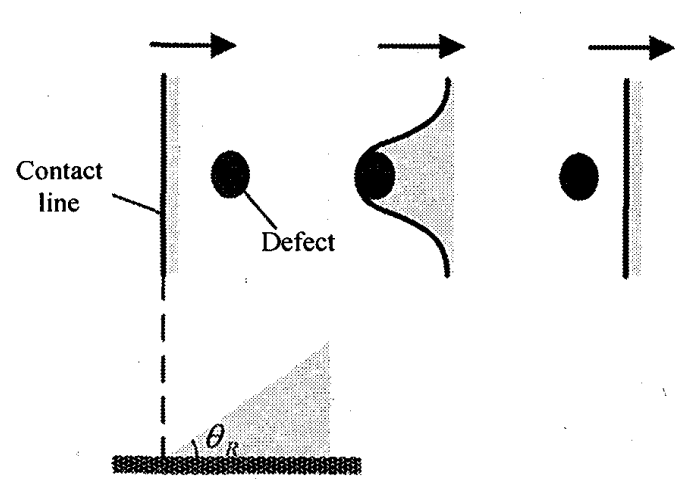

Fig .2 Movement of three-phase contact line over a defect on solid surface
模式的に表わしたものである. 水平板上の液滴の場合, 図 2 の $\theta_{\mathrm{R}}$ の位置が後端の接触線に対応する. 局所的に 存在する欠陥部に接触線の一部がトラップされる結果, その歪み形成に応じたエネルギーの分だけ抵抗が増加 する. 巨視的に観察される接触角は，そのエネルギー 増加の影響を受け，いわゆる平衡接触角とは異なる角 度が接触線の移動方向に依存して現れる. 接触角履歷 そのものを具体的に求める手法は未だ構築されていな いが, 図2のモデルにより，そのメカニズムは定性的 に説明できると考えられる.

固体面上に振動などの外乱を与えると, 接触角はエ ネルギー最小条件を満足する平衡接触角に近づくこと が実験的に示されている(14)(15). 図2 のモデルに従えば, 振動を付加すると，欠陷部を乗り越える際の抵抗が小 さくなる. その結果, エネルギ一増加量が抑制され, 接触角履歴の低減が期待できる. 本研究では, 液滴が 置かれる平板に垂直方向の微小振動を与え, 式(1)の抵 抗を低减する方法について検討する. 図 2 のモデルよ り，接触角履歴に影響を与えるのは微小スケールの欠 陷であり，振動としてはできる限り高周波のものが望 まれる. 例えば, 表面張力に伴う液体振動周波数の代 表值 $f(1 / \mathrm{s})$ として,

$$
f \sim \sqrt{\sigma / \rho l^{3}}(\rho: \text { 密度, } l: \text { 長さスケール) }
$$

を考えると, 液滴のスケールとして, $l \sim 1 \mathrm{~mm}$ を考え ても $f 100 \mathrm{~Hz}$ となる. 欠宿部のスケールを考えた場合 には，より高い周波数の振動が効果的と予想される. また, 接触線の歪みのスケールが液滴よりも微小であ ることを考え, ここでは, 高周波かか微小振幅による 振動を与えることとした. 本実験では, 試みとして数 $10 \mathrm{kHz}$ で数 $\mu \mathrm{m}$ の振幅をもつ超音波振動子を用いた.

$2 \cdot 2$ レ一ザーによる液滴駆動 従来, 温度上昇 に伴う表面張力の減少を利用した液滴や液柱の駆動方 法が提案されている. 固体面上の液滴については，壁 面に電極などを埋め込み，通電加熱などにより壁面に 温度勾配を与える手法の検討が行われている ${ }^{(3 \times 5)(6)}$ 。低 温側の表面張力が高くなる結果, 液滴は温度の低い方 向に移動する.この方法では, 壁面に電極パターンな どの加工が必要になり, またパターンに応じた運動し か得られない不自由さがある. 一方, 外部から自由に 運動制御を行うため, レーザーを液滴に照射し，その 加熱による表面張力低減効果を利用した報告が認めら れる(16)(17)。これらの報告では, 接触角が $180^{\circ}$ に近い 特殊な固体面を対象として，レーザーによる液滴の運 動について検討が行われている.ここでは，より一般 的な $90^{\circ}$ 以下の接触角をもつ場合を対象として, 上記 
壁面振動とレーザ一照射を組み合わせ，固体面上の液 滴を駆動する新たな手法を提案する、レ一ザーによれ ば，スポット的な加熱により局所に高温の状態が実現 できるため, ぬれ性の顕著な変化を誘起することが予 想できる. すなわち, 固液の接触角の温度依存性が顕 著な場合, 高温下でのぬれ性の変化により液滴か駆動 される場合が考えられる. 式(1)より，レーザ一照射位 置の接触角が常温の後退接触角よりも小さくなると, 液滴は加熱端の方向に向かって運動する. 今回は, 次 章で示す, 自己組織化単分子膜(SAMs)を施した表面を 対象として, 表面特性が加熱の影響を受けやすい平板 上での液滴挙動について検討を行う。

\section{3. 実験装置および方法}

$3 \cdot 1$ 実験装置概略 図 3 に, 本実験で用いた装置 の模式図を示吉. 共振周波数 $28 \mathrm{kHz}$ の超音波振動子( ジセラミック, FBL 28452HS)の振動面上に試料板を載 せ，所定の体積の軸対称液滴をマイクロシリンジで設 置寸る. 超音波振動子の共振周波数に合わせながら電 圧および電流を変化させ, 数種類の振動振幅を設定し た. 振動させた状態で試料平板を傾け，液滴が転落す る瞬間での画像ざデジタルカメラにより撮影し, 液滴 先端(後端)の前進(後退)接触角を測定した. なお, 軸対 称液滴の接触角を測定する場合, ラプラスの方程式を 利用して液滴形状を理論的に算出し，その壁面での勾 配より求める手法の精度が高い(18). しかしながら，振 動を与えた状況下での液滴形状は, ラプラスの方程式 の解とは一致しなかった。ここでは，上述の液滴画像 をPCに取り込み，その壁面近傍での形状を多項式近 似し，その勾配より接触角を求めた。接触角は，同じ 実験条件下で 6 回以上測定し，その平均值を採用した。 本実験における接触角の測定精度は， $\pm 1^{\circ}$ 程度であ

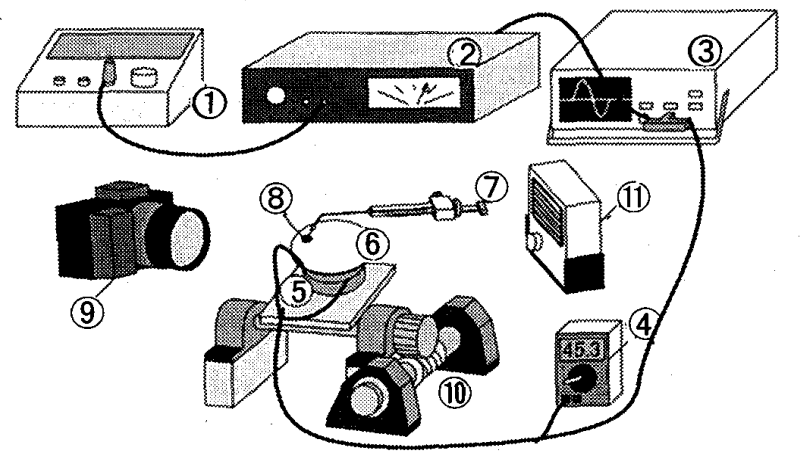
(1) Function Generator
(2) Amplifier
(3) Oscilloscope
(4) Ammeter
(5) Supersonic oscillator

(6) Test Plate

(7) Micro syringe

(8) Droplet

(9) Digital camera

(110) Worm gear set

(11) Antistatic blower

Fig.3 Schematic diagram of experimental apparatus
る.

式(1)の液滴移動に対する表面張力による抵抗の, 超 音波振動の付加による変化を見るため, 転落が生じる ときの傾き角度の測定も合わせて行った．転落角度の 測定は，既報と同じ方法により行った ${ }^{(7)(8)}$. 転落角度の 測定誤差は土0.3 0. である.

壁面を超音波振動させた状態で, 図4のように, 試 料平板に対して約 $60^{\circ}$ の角度から, 液滴周端より内側 にスポット径約 $0.1 \mathrm{~mm}$ のレーザー光線(Mellesgriot,

Model 85-GHS-305)を照射した.レーザ一光の波長は $532 \mathrm{~nm}$ で, 出力 $W$ を $10 \mathrm{~mW}$ 力ら $200 \mathrm{~mW}$ の範囲で変化 させ，接触角ならびに液滴運動の観察を行った。

3-2 壁面振動の振幅測定 超音波振動子壁面の振 動振幅を, 図 5 に示すフィゾ一干渉計により測定した. ビームエキスパンダーおよびビームスプリッタを通過 したレーザー光は, ウェッジプリズムを通過して，振 動子表面に設置した試料平板に導かれる. 図 5 右の拡 大図のように，プリズム(8)は測定面より隙間 $h$ をもつ て平行に設置されている. プリズム下端の参照面およ び測定面からの反射光の重水合わせにより，千涉縞が 形成される. 測定面上の干涉縞の明暗は, 振動子の変 位に応じて時間的に変化する. その信号を図 5 の光セ ンサー(4)により受光し, 出力電圧がオシロスコープに 取り込まれる構造となっている.

図6にオシロスコープ上の電珐波形の一例を示す. 振動子表面の変位に伴い, 図 5 右拡大図中の陌間 $h$ が 時間変化し, $2 h$ がレーザー光波長 $\lambda(=632.8 \mathrm{~nm})$ の整数

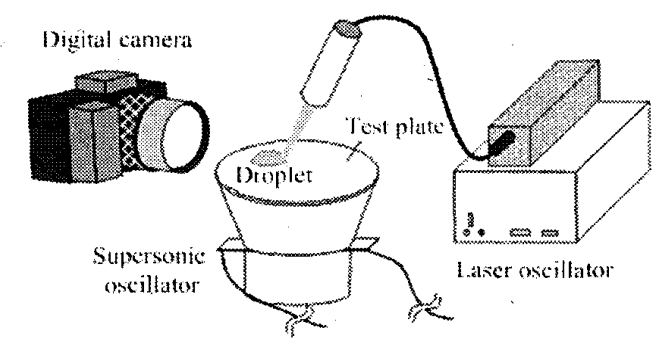

Fig. 4 Laser beam directed to droplet on oscillated plate

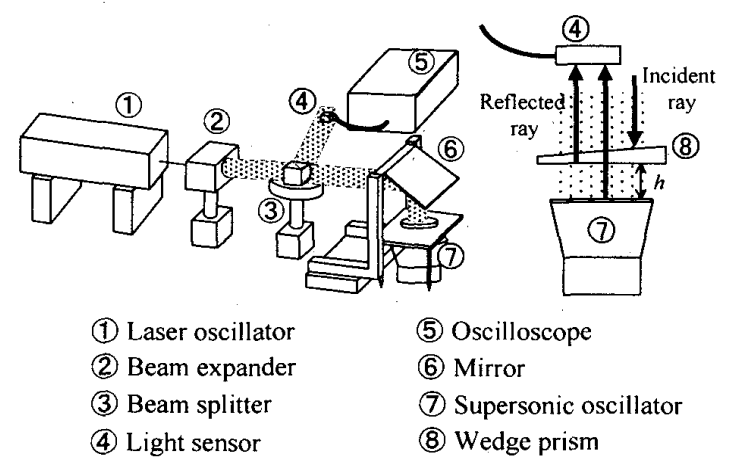

Fig. 5 Optical system to measure amplitude of supersonic oscillator 


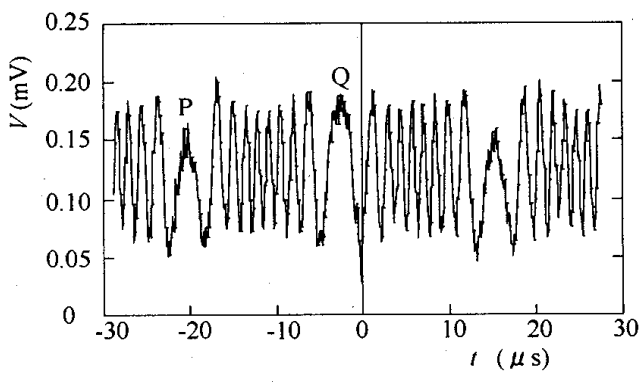

(a) Output of oscilloscope

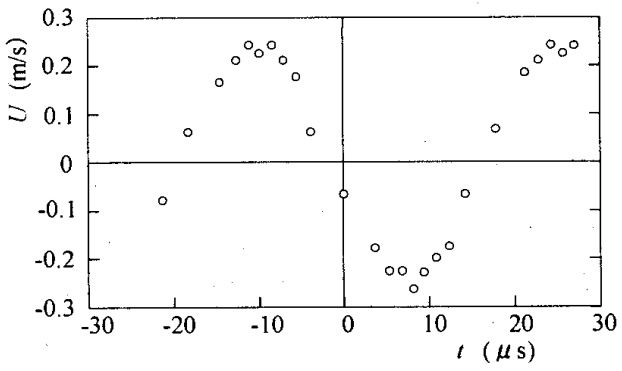

(b) Displacement velocity

Fig. 6 Output from the interference fringe on surface of supersonic oscillator

倍に等しくなったとき，反射光同士が強め合うため， 図 6(a)の波形にピークが現れる．振動子の変位速度に 対応して, 隣り合うピークの時間間隔 $\Delta t$ は周期的に変 化する. $\lambda 2$ を $\Delta t$ で除した量は，その時刻の振動子変 位速度 $U$ に等しい. 各時刻における振動子変位速度を 図 6(a)から求めた結果を図 6(b)に示す．振動に応じて 速度が正弦波状に変化していることがわかる．振動子 変位の半周期として，例えば図 6(a)中の点 $\mathrm{P}, \mathrm{Q}$ を選 べば，その間に入る波の数 $M$ より，振動子の振幅 $A$ を次式より求めることができる.

$$
A=\frac{M}{2} \cdot \lambda
$$

振動子に与える電圧ごとに 6 回以上の測定を行い，各 電圧に対する振幅を求めた。半周期に含まれる波の数 $M$ は，1/10 波長の精度で測定した．本実験で用いた振 動子の場合，振幅の標準偏差は 5\%程度であつた。な お，振動子の振幅は，試料板上の位置によって必ずし も一定ではないので，液滴は常に振幅が測定された同 じ位置に設置して実験を行った，表 1 に，設定電圧 $V$ に対する振幅の測定結果を示す．本実験で用いた振動 子の場合，振幅はほぼ電圧の平方根に比例する結果と

Table 1 Amplitude of supersonic oscillator

\begin{tabular}{c|c}
\hline \hline$V(\mathrm{~V})$ & $A(\mu \mathrm{m})$ \\
\hline 10 & 2.8 \\
\hline 15 & 3.2 \\
\hline 20 & 3.8 \\
\hline 25 & 4.3 \\
\hline
\end{tabular}

なった。

3 -3 試料平板および試料液体 本実験では, 試料 平板として，日本曹達(株)が開発した浸漬法により $\mathrm{Si}$ ウェハ一表面に自己組織化単分子膜(Self Assembled Monolayers，以下 SAMs と記す)を施した固体表面を用 いた ${ }^{(8)}$. SAMs 板は表面の凹凸が $1 \mathrm{~nm}$ 程度と非常に滑 らかであり, 分子レベルで秩序的な配向を有するため, 接触角履歴が数度と通常の表面よりもかなり小さい ${ }^{(8)}$. 式(1)からわかるように, 液滴を駆動するのに必要な外 力を小さくすることが期待できる. また, 表面が秩序 的な構造をもつため, 後述するレーザー光によるラン ダムな熱振動の分子配列に与える影響が大きく，ぬれ 性が顕著に変化することが期待できる.

供試夜体として，ここではブチルカルビトールアセ

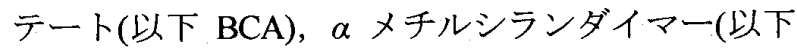
$\alpha \mathrm{MSD})$ ，およびグリセリンを用いた，本実験では，液 滴にレーザーのエネルギーを効率的に吸収させるため, 液滴の移動実験を行った $\alpha \mathrm{MSD}$ および BCA について は，染料としてズダン III を 2500ppm 加えた。 なお， レーザーの波長を変えれば，無色の液体についても熱 を吸収させることは可能である(17).

基準温度 $\left(20^{\circ} \mathrm{C}\right)$ における各供試液体の物性值を表 2 に示す。ここで，密度はボーメの比重計，表面張力は 電子天秤を用いた Wilhelmy の吊り板法により測定し た．表中には，温度 $T$ による表面張力の変化率 $(d \sigma / d T)$ の測定結果も示してある．なお，表 2 ならびに以下に 示す測定值は，すべて染料を含んだ場合の結果を示し ている. 実際には, 染料添加による物性值の変化は, 測定誤差の範囲内であった。

\section{4. 実験結果および考察}

4-1 超音波振動による接触角履歴の変化 図 7 に，各供試液体のSAMs 試料板に対する接触角の，振 動振幅 $A$ に対する変化を示す。液滴の体積は, $1 \mu \mathrm{L}\left(\equiv 1 \mathrm{~mm}^{3}\right)$ である. 図 7(a)〜 (c)より, 各供試液体とも, 振動振幅の堌加とともに前進接触角 $\theta_{\mathrm{A}}$ は減少し, 後退 接触角 $\theta_{\mathrm{R}}$ はわずかに減少する傾向を示した. その結果， 両者の差である接触角履歷は，振動振幅とともに減少 した. 本実験よりも大振幅で低周波数の振動を与えた 場合，前進接触角は诚少し，後退接触角が増加して両 者の差が小さくなる傾向が示されている(14). 本実験で

Table 2 Physical property of test liquids

\begin{tabular}{c|c|c|c}
\hline \hline & $\rho\left(\mathrm{kg} / \mathrm{m}^{3}\right)$ & $\sigma(\mathrm{N} / \mathrm{m})$ & $d \sigma / d T \times 10^{3}$ \\
\hline$\alpha \mathrm{MSD}$ & 990 & 0.0365 & -0.084 \\
\hline BCA & 984 & 0.0304 & -0.080 \\
\hline Glycerol & 1260 & 0.0644 & - \\
\hline
\end{tabular}


扱った均質な表面におけるぬれ挙動において，2つの 接触角ともに減少する理由については不明であり，今 後の検討課題としたい.

振動子を駆動した状態で, 電磁場測定器(CUSTOM 社製，TFM-60)により試料板回りの電磁場を測定した. その結果，わずかな電場ならびに $4 \mathrm{mG}$ 程度の磁場の 存在が認められた。しかしながら，振動子を動作させ た状態で試料平板をわずかに振動面より離した場合，

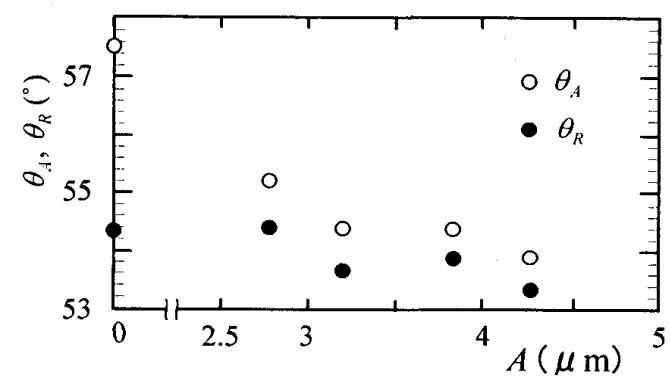

(a) $\alpha \mathrm{MSD}$

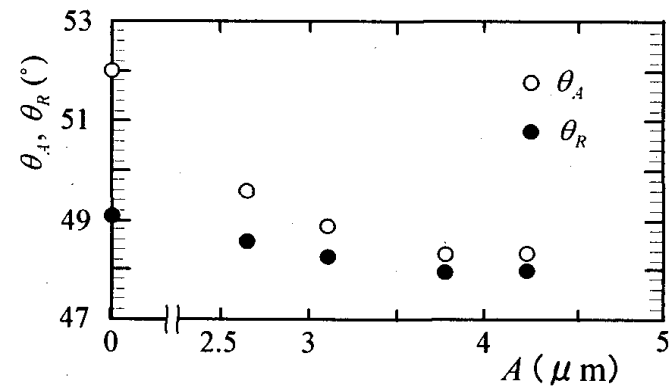

(b) BCA

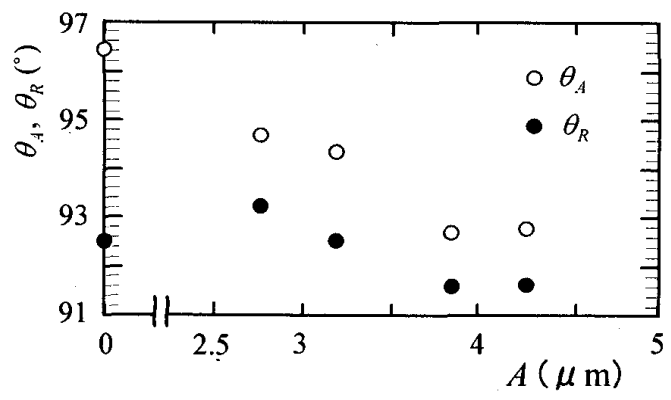

(c) Glycerol

Fig.7 Change of contact angle with the amplitude of supersonic oscillator

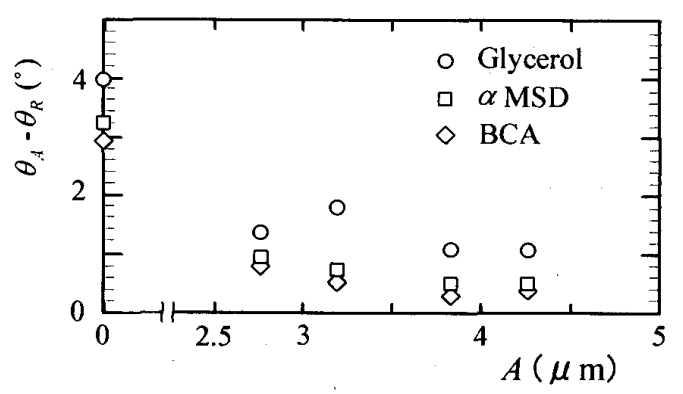

Fig. 8 Change of contact angle hysteresis with respect to the amplitude of supersonic oscillator
接触角の測定值は静止状態の值にほぼ一致した.また, 試料板近傍に外部から上記よりも大きな電場およひ磁 場を強制的に与えた場合，接触角は振動のないときの 值にほぼ一致することが確認できた。図 7 に示した接 触角の測定結果に対し，電場や磁場の影響は小さいと 考えられる.

前進・後退接触角の差である接触角履歷の值を図 8 に示す．接触角履歷 $\left(\theta_{\mathrm{A}}-\theta_{\mathrm{R}}\right)$ は振幅とともに減少し, しだいに一定の值に漸近する傾向が認められた．超音 波振動を与えることで，静止状態における $3 \sim 4^{\circ}$ の接 触角履歴は $1^{\circ}$ 程度にまで低減され，結果として式(1) の抵抗を小さくすることができる．表 3 は，振幅 $A=3.2 \mu \mathrm{m}$ において， $\alpha \mathrm{MSD}$ および BCA に対し，液滴 体積V/を変化させたときの接触角の測定結果を示して いる．体積によらず，ほぼ同程度の接触角履歴の低减 効果が認められた。

$1 \mu \mathrm{L}$ の液滴の転落角度を振動振幅ごとに測定した結 果を図 9 に示寸。図中には，軸対称液滴を対象とした 理論值が比較のため示されている．転落角度の理論值 は，次式より算出を行った(7)(9).

Table 3 Contact angles at various volumes $(A=3.2 \mu \mathrm{m})$

\begin{tabular}{c|c|c|c|c|c|c}
\hline \hline & \multicolumn{3}{|c|}{$\alpha \mathrm{MSD}$} & \multicolumn{3}{c}{$\mathrm{BCA}$} \\
\hline$V_{l}(\mu \mathrm{L})$ & $\theta_{\mathrm{A}}$ & $\theta_{\mathrm{R}}$ & $\theta_{\mathrm{A}}-\theta_{\mathrm{R}}$ & $\theta_{\mathrm{A}}$ & $\theta_{\mathrm{R}}$ & $\theta_{\mathrm{A}}-\theta_{\mathrm{R}}$ \\
\hline 1 & 54.8 & 54.0 & 0.8 & 49.4 & 47.9 & 1.5 \\
\hline 3 & 54.0 & 53.2 & 0.8 & 49.5 & 48.3 & 1.2 \\
\hline 5 & 53.5 & 52.7 & 0.8 & 49.2 & 47.5 & 1.3 \\
\hline 7 & 53.1 & 52.6 & 0.5 & 48.7 & 47.2 & 1.5 \\
\hline
\end{tabular}

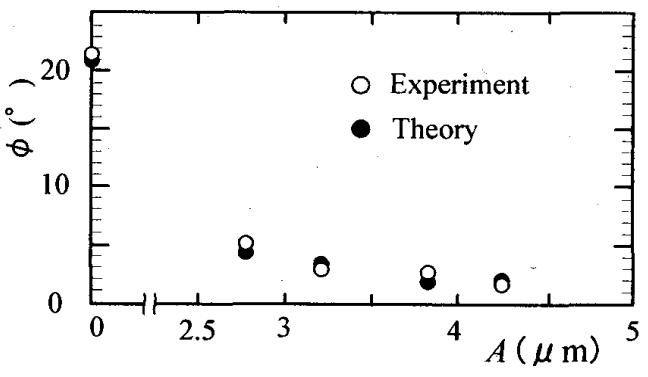

(a) $\alpha \mathrm{MSD}$

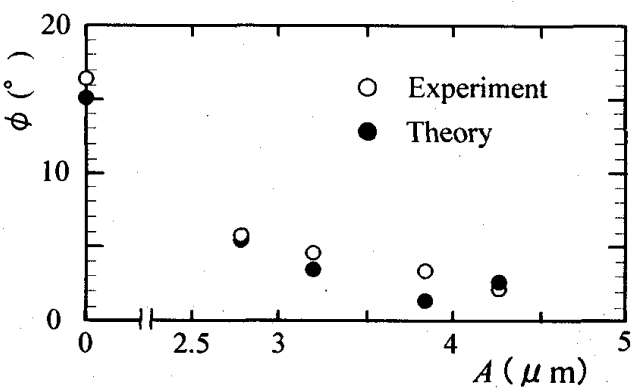

(b) BCA

Fig.9 Inclination angle of oscillated plate at which droplets . start to slide 


$$
D=\sigma\left(\cos \theta_{R}-\cos \theta_{A}\right) b=\rho g V_{1} \sin \phi
$$

ここで， $\phi$ は壁面の傾斜角度である. 軸対称液滴を水 平板上に設置後, 板を傾けた場合, 液滴幅は一定に保 たれる. 上式において, 左辺の液滴幅 $b$ に, 水平板上 の液滴径の測定值を代入して $\phi$ を算出した. 図9より, 測定結果は式(3)によりほぼ整理できることがわかる. 接触角履歷が小さい結果, 接触角の測定誤差に対して 式(3)左辺の值が敏感に変化する. 理論值と実験值の差 は，主に接触角の測定誤差に起因する，図9より, 転 落角度 $\phi$ は, 振動振幅の増加とともに減少寸る傾向を 示す，本実験における最大の振幅を与えた場合，転落 角度は静止状態から約 $15^{\circ}$ 低減した. 式(3)右辺から見 積もられる移動抵抗から，本実験で用いた振動子によ り， $1 \mu \mathrm{L}$ の液滴を移動させるのに要する力を約 $80 \%$ 低 減することができた，この結果は，接触角履歴の減少 に起因するものであり，壁面振動が液滴の移動抵抗低 減に効果のあることがわかる.

\section{4-2 レ一ザーによる液滴駆動＼cjkstart前節で述べた振} 動を与えた状態で, レーザー光を液滴の一端に照射し た. その結果, あるレーザーの出力以上で液滴全体が レーザー照射端の方向に移動することが観察された。

このとき，連続して $10 \mathrm{~mm}$ 以上液滴が移動することを 確認している.

本報告では，レーザー照射による液滴駆動のメカニ ズムを把握する第一段階として, 液滴が移動するまで の接触角の変化ならびにレーザー出力と液滴移動速度 の関係に対する測定結果を述べる.より詳細な液滴駆 動のメカニズムについては，次報で検討を行う．

図 10 は, 時間 $t(\mathrm{~s})$ により変化する液滴の様子を撮影 した連続写真の一例である.レーザーは軸対称液滴の 右端に照射されている. 初期の図 10(a)の状態で, 液滴 は図7中の各振幅に対する前進接触角 $\theta_{\mathrm{A}}$ で接している. 図 10(a)の照射開始から時間が経過すると，レーザ一照 射端の接触角が徐々に減少していく。これは，レーザ 一による温度上昇により，固液の親和性が変化し，ぬ れ性が向上したことによると考えられる. 図10(d)の状

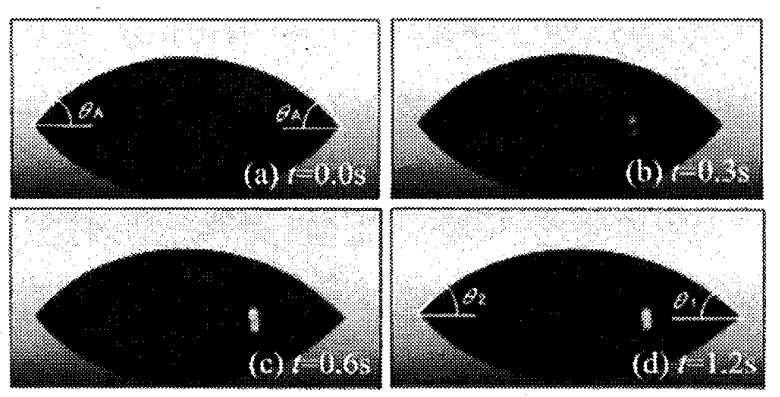

Fig.10 Photograph of droplet behavior when Laser beam is directed on the right end of the droplet ( $\alpha M S D$ )
態になると，照射端の接触角 $\theta_{1}$ が他端の接触角 $\theta_{2}$ より もかなり小さくなり，表面張力の作用によって液滴全 体が右方向一移動を開始する. すなわち, 高温側の表 面張力は小さくなるが, 接触角の減少が顕著なため, 表面張力の壁面接線方向の合力が右方向に作用する結 果, 液滴は高温側に向かって移動すると考えられる.

図 10 のように液滴が移動する条件において, レ一ザ 一照射後の接触角の時間変化を測定した. $\alpha \mathrm{MSD}$ に対 する測定例を図 11 に示す. 図中の点線は, 液滴が移動 を開始した時刻を表す。図11(a), (b)なごの異なる条件 下においても，接触角は類似な挙動を示した。 すなわ ち, 照射位置の接触角 $\theta_{1}$ は, レーザ一照射後急激に減 少する. その後, 减少の度合いは緩やかになり, 一定 值に落ち着く傾向を示す. 1 秒程度の時間が経過した のち, 液滴は移動を開始する、レーザー出力の大きい 図11(a)の方が，移動までに要する時間は短い，照射初 期の接触線近傍の急加熱により, $\theta_{1}$ は急激に減少する. 液滴は, 最初 $20^{\circ} \mathrm{C}$ における前進接触角 $\theta_{\mathrm{A}}$ で設置され ているため, 液滴が $\theta_{1}$ の減少により右方向に引つ張ら れる結果, 他端の $\theta_{2}$ は $\theta_{\mathrm{A}}$ より減少して, 後退接触角 $\theta_{\mathrm{R}}$ に近づく，接触角が $\theta_{\mathrm{R}}$ に達するまでの変形のため, 液 滴が移動を開始するまでに，やや時間を要すると考え られる. なお，振動子の振幅を 0 から最大值の $4.3 \mu \mathrm{m}$ まで変化させて実験を行った結果, 図 11 と定性的に同 じ挙動が認められた。

液滴が移動できる臨界条件について検討を行った. ここでは, レーザーを 1 分間照射して, 液滴が

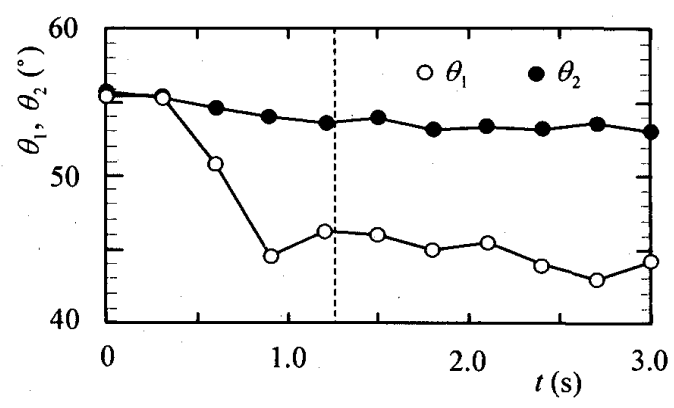

(a) $A=2.8 \mu \mathrm{m}$, output of Laser $48 \mathrm{~mW}$

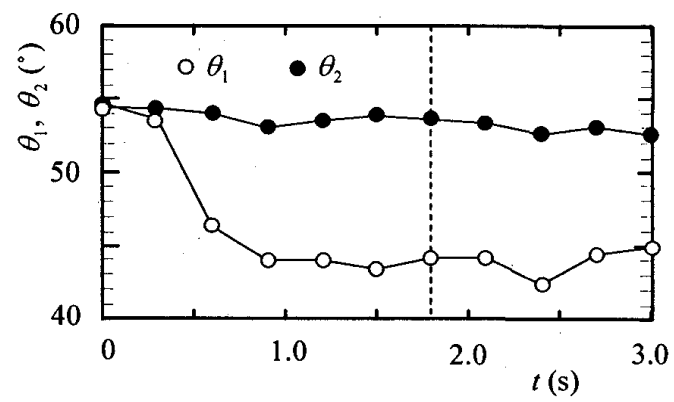

(b) $A=3.8 \mu \mathrm{m}$, output of Laser $30 \mathrm{~mW}$

Fig. 11 Contact angle change after Laser beam was directed on the droplet ( $\alpha M S D$ ) 
Table 4 Laser power necessary to actuate droplet

\begin{tabular}{c|c|c}
\hline \multirow{2}{*}{$A(\mu \mathrm{m})$} & \multicolumn{2}{|c}{ Laser output (mW) } \\
\cline { 2 - 3 } & aMSD & $\mathrm{BCA}$ \\
\hline 0 & 95 & 76 \\
\hline 2.8 & 33 & 37 \\
\hline 3.2 & 27 & 15 \\
\hline 3.8 & 20 & 10 \\
\hline 4.3 & 20 & 17 \\
\hline
\end{tabular}

$0.05 \mathrm{~mm} / \mathrm{min}$ の速度以上で移動することが確認できた ときを臨界条件と見なした．表 4 は，種々の振動振幅 に対し， $1 \mu \mathrm{L}$ の液滴が移動を開始する臨界のレーザー 出力を測定した結果を示したものである．振幅の増加 により臨界出力の值は減少し，一定値に落ち着く傾向 を示した.これは接触角履歷(図 8)や液滴が転落する平 板の傾斜角度(図9)上同じ傾向であり, 振動による移動 抵抗の低減効果の結果と考えられる。

図 12 は, 臨界条件において, 液滴が移動する瞬間で の写真例である.このとき，両端に作用する表面張力 は，近似的に次式を満足していると考えられる.

$$
\sigma_{1} \cos \theta_{1}=\sigma_{2} \cos \theta_{2}
$$

ここで， $\sigma_{1} ， \sigma_{2}$ は，それぞれレーザー照射側ならびに 他端の表面張力を示している.図 12 の移動開始時にお いて, $\theta_{1}=48.4^{\circ}, \theta_{2}=52.6^{\circ}$ である. 表 1 中の $(d \sigma / d T)$ の值を用い，式(4)が成立するときの表面張力を見積も ると, 液滴の両端で約 $40^{\circ} \mathrm{C}$ の温度差が存在すると見積 もられる，なお，実際の液滴の温度上昇および接触角

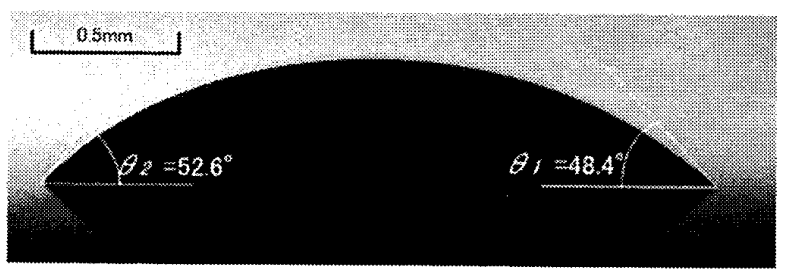

Fig. 12 Contact angle at the critical condition when droplet starts to slide ( $\alpha \mathrm{MSD}, \mathrm{A}=3.8 \mu \mathrm{m}$, output of Laser $=20 \mathrm{~mW}$ )

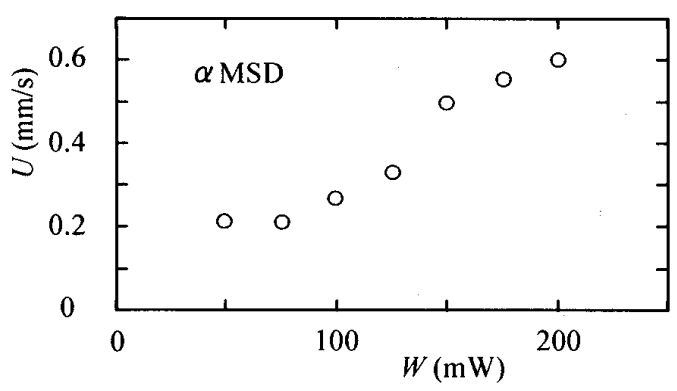

Fig.13 Droplet velocity induced by Laser
の温度変化，ならびに液滴が移動する臨界条件につい ては, 次報で詳しく考察する。

今回の実験における最大振幅 $A=4.3 \mu \mathrm{m}$ の振動を与 えたとき, 各レーザ一出力における液滴の移動速度を 測定した結果を図 13 に示す. 出力に対し, 移動速度は 直線的に増加する. 本実験条件下では, 最大で $0.6 \mathrm{~mm} / \mathrm{s}$ の移動速度を得ることができた。

\section{5. 結 言}

超音波振動子により壁面に高周波( $28 \mathrm{kHz})$ の振動を 与え, 液滴之固体面との接触角履歴の大きさを低减し た上で, 液滴をレーザ一照射により移動させる手法に ついて実験的に検討を行った. 主な結論を以下に記す。

（1）接触角履歴の小さいSAMs 板に超音波振動を与え たところ，3 種類の液体ともに接触角履歷が数 減少 する効果が認められた。本実験における最大振幅 $4.3 \mu \mathrm{m}$ のとき, $1 \mu \mathrm{L}$ の液滴の転落角度は約 $15^{\circ}$ 減少し, 液滴が移動するときの抵抗を約 $80 \%$ 低减できた.

（2）超音波振動を与えた状態でレーザーを照射した ところ, 照射端の接触角が加熱により顕著に減少する 現象が認められた. その結果, 液滴に作用寸る表面張 力の合力が現れ，液滴はレーザー照射端の方向に移動 することが観察された. 本実験範囲では，液滴を最大 $0.6 \mathrm{~mm} / \mathrm{s}$ の速度で移動させることができた.

謝辞 本研究の一部は, 文部科学省科学研究費補助金 (課題番号 20560165)の援助を受けた．謝意を表す．

\section{文献}

(1) Dahuber, A. A. and Troian, S. M., Principles of Microfluidic Actuation by Modulation of Surface Stresses, Annual Review of Fluid Mechanics, 37(2005), 425-455.

(2) Daniel, S., Chaudhury, M. K. and de Gennes, P. G., Vibration-actuated drop motion on surfaces for batch microfluidic processes, Langmuir, 21(2005), 4240-4248.

(3) Chen, J. Z., Troian, S. M., Darhuber, A. A. and Wagner, S., Effect of contact angle hysteresis on thermocapillary droplet actuation, Journal of Applied Physics, 97(2005), 014906, 1-9.

(4) Shastry, A., Case, M. J. and Böhringer, K. F., Directing droplets using microstructured surfaces, Langmuir, 22(2006), 6161-6167.

(5) Pratap, V., Moumen, N. and Subramanian, R. S., Thermocapillary motion of a liquid drop on a horizontal solid surface, Langmuir, 24(2008), 5185-5193.

(6) Mettu, S. and Chaudhury, K., Motion of drops on a surface induced by thermal gradient and vibration, Langmuir, 24(2008), 10833-10837.

(7) Katoh, K., Azuma, T., Higashine, M. and Miyamoto, Y., On the sliding down of liquid drops on inclined plates (1st report, critical inclination angles of plates), 
Transactions of the Japan Society of Mechanical Engineers, Series B, 72(2006), 1287-1294.

(8) Katoh, K., Higashine, M., Nakamoto, N. and Azuma, $\mathrm{T}$., On the sliding down of liquid drops on inclined plates (2nd report, Sliding angles on SAMs surfaces), Transactions of the Japan Society of Mechanical Engineers, Series B, 73(2007), 1548-1555.

(9) Katoh, K., Nishida, T. and Higashine, M., On the Sliding down of Liquid Droplets on Inclined Plates (Sliding Volume of Liquid Droplets), Transactions of the Japan Society of Mechanical Engineers, Series B, 75(2009), 1135-1142.

(10) Nishida, T., Katoh, K. and Wakimoto, T., Critical volume of liquid droplets attached to a vertical cylinder, Transactions of the Japan Society of Mechanical Engineers, Series B, 75(2009), 2273-2279.

(11) Katoh, K., Higashine, M., Wakimoto, T. and Masuda, $\mathrm{R}$., On the sliding and profile of a liquid droplet on a rotating disk, Transactions of the Japan Society of Mechanical Engineers, Series B, 73(2009), 796-803

(12) de Gennes, P. G., Brochard-Wyart, F. and Quéré, F.,
(Translated by Okumura, K.), Gouttes, bulles, perles et ondes, (in Japanese), (2003), 67-84, Yoshioka-Shoten.

(13) Katoh, K., On the contact angle hysteresis and sliding down of a liquid droplet on inclined surfaces, Journal of the Heat Transfer Society of Japan, 46(2007), 20-27.

(14) Decker, E. L. and Garoff, S., Using vibrational noise to probe energy barriers producing contact angle hysteresis, Langmuir, 12(1996), 2100-2110.

(15) Volpe, C. D., Maniglio, D., Morra, M. and Siboni, S., The determination of a 'stable-equilibrium' contact angle on heterogeneous and rough surfaces, Colloids and Surfaces, A: Physicochemical and Engineering Aspects, 206(2002), $47-67$.

(16) Kotz, K. T., Noble, K. A. and Faris, G. W., Optical microfluidics, Applied Physics Letters, 85(2004), 2658-2660.

(17) Shukla, R. and Kallam, K. A., Effect of liquid transparency laser-induced motion of drops, Transactions of $A S M E$, Journal of Fluids Engineering, 131(2009), 081301, 1-7.

(18) Kalantarian, A., David, R. and Neumann, A. W., Methodology for high accuracy contact angle measurement, Langmuir, 25(2009), 14146-14154. 